\title{
BAHASA ARAB DAN PSIKOLINGUISTIK: Kajian Konseptual dan Historis
}

\author{
Zulhannan \\ e-mail: zulhannan@radenintan.ac.id \\ UIN Raden Intan Lampung
}

\begin{abstract}
Penelitian ini diawali persoalan substansial mengapa bahasa Arab dan psiko-linguistik harus dikaji secara konseptual dan historis? dengan tujuan penelitian men-deskripsikan keniscayaan bahasa Arab dan psikolinguistik dikaji secara konseptual dan historis. Sedangkan penelitian ini dapat memberikan kontribusi teoritis dan kontribusi praktis. Dimana kontribusi teoritis dapat dijadikan paradigma baru bagi peneliti beri-kutnya untuk mengadakan studi tentang relevansi bahasa arab dan psikolinguistik: kajian historis dan konseptual. Sementara kontribusi praktis, bahwa psikolinguistik dapat diaktualisasikan dalam pembelajaran bahasa Arab di era globalisasi saat ini, dimana kedua disiplin ilmu ini tidak akan menemukan titik final yang berakhir pada suatu muara tertentu, sebab selalu berkembang dan update pada setiap era (masa). Penelitian ini merupakan studi kepustakaan (library research) dengan cara menela'ah aneka literatur yang terkait. Sedangkan metode yang akan diterapkan dalam penelitian ini adalah deskriptif dan analisis. Kedua metode ini tidak diterapkan satu persatu, akan tetapi diterapkan secara serentak. Metode deskriptif dipakai, karena dalam uraiannya akan memberikan gambaran umum tentang persoalan yang akan dikaji, kemudian dari data tersebut akan diadakan interpretasi. Sementara metode analisis digunakan untuk melihat secara kritis berbagai persoalan yang melatar belakangi persoalan tersebut. Untuk prosedur pengolahan data, digunakan Content Analysis. Mencermati paparan dimaksud, maka temuan penelitian yang dihasilkan adalah "Desain Psikolinguistik dalam Pembelajaran Bahasa Arab”, dimulai dari desain tujuan, desain materi, desain pendekatan, desain metode, desain teknik, desain media pembelajaran serta desain evaluasi proses dan evaluasi hasil.
\end{abstract}

Keywords: Bahasa Arab, Psikolinguistik, Konseptual dan Historis

\section{PENDAHULUAN}

Berbicara persoalan bahasa Arab dalam konteks Psikolinguistik memang sangat menarik dan meng-gairahkan, bahkan tidak akan mene-mukan titik final yang berakhir pada suatu muara tertentu. Karena kedua disiplin ilmu tersebut selalu berkem-bang pada setiap era dan masa. Bahasa Arab yang banyak dipahami oleh para pakar dan pem-belajar bahasa merupakan salah satu bahasa $\underline{\text { Semit }}$ Tengah, yang masih dalam rumpun bahasa Semit ${ }^{1}$ serta berkera-bat

\footnotetext{
${ }^{1}$ Semit adalah satu-satunya subrum-pun bahasa Afro-Asia yang berasal dari luar Afrika. Beberapa penutur bahasa Semit menyeberang dari Arab Selatan ke Ethiopia, sehingga beberapa bahasa di Ethopia (seperti bahasa Amhar) merupakan bahasa dari rumpun Semit. (Minoritas
}

dengan bahasa Ibrani dan berba-gai bahasa Neo Arami. Di samping, bahasa Arab memiliki lebih banyak penutur dari pada aneka bahasa lain-nya dalam rumpun bahasa Semit. Bahkan ia dituturkan oleh lebih dari 280 juta orang sebagai bahasa per-tama, yang mana sebagian besar tinggal di Timur Tengah dan Afrika Utara. Bahasa ini juga adalah bahasa resmi dari 25 negara, dan merupakan bahasa peribadatan dalam agama Islam, karena merupakan bahasa

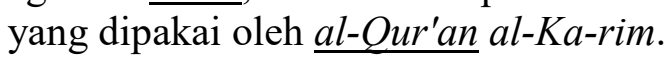

akademisi, seperti A. Murtonen (1967), menentang pandangan ini, mengusulkan bahwa bahasa Semit mungkin berasal dari Ethiopia). (Wikipedia Bahasa Indonesia tentang Rum-pun Bahasa Semit). 
Sementara berdasarkan penye-baran geografisnya, bahasa Arab lisan memiliki banyak variasi (dia-lek), beberapa dialeknya bahkan ti-dak dapat saling mengerti satu sama lain. Sedangkan bahasa Arab modern telah diklasifikasikan sebagai satu makrobahasa dengan 27 sub-bahasa dalam ISO 6393. ${ }^{2}$ Adapun bahasa Arab Baku (kadangkadang disebut bahasa Arab sastra) diajarkan secara luas di sekolah, universitas, dan di-gunakan di tempat kerja, pemerin-tahan, serta media massa. Lebih jauh ditegaskan bahwa bahasa Arab baku berasal dari bahasa Arab klasik, satu-satunya anggota rumpun bahasa Arab Utara Kuno yang saat ini masih digunakan, sebagaimana tampak dalam inskripsi peninggalan Arab pra Islam yang berasal dari abad ke-4. Bahasa Arab klasik juga telah menjadi bahasa kesusasteraan dan bahasa peribadatan Islam sejak lebih kurang abad ke-6. Abjad Arab ditulis dari kanan ke kiri. Di sisi lain, bahasa Arab telah memberi banyak kosakata kepada bahasa lain dari du-nia Islam, sama seperti peranan La-tin kepada kebanyakan bahasa Eropa. Semasa Abad Pertengahan bahasa Arab juga merupakan alat utama budaya, terutamanya dalam sains, matematika dan falsafat, yang me-nyebabkan banyak bahasa Eropa turut meminjam banyak kosakata dari bahasa Arab dimaksud.

Sedangkan psikolingustik ada-lah ilmu yang mempelajari perilaku berbahasa, baik prilaku yang tampak maupun perilaku yang tidak tampak. Untuk lebih jelasnya, terkait penger-tian psikolinguistik dipaparkan oleh beberapa pakar berikut. Aitchison (dalam

${ }^{2}$ ISO 639-3, are the Codes for the representation of names of languages-Part 3 : Alpha-3 code for comprehensive coverage of languages, is an international standard for language codes in the ISO 639 series. It defines three-letter codes for identifying languages. The standard was published by $\underline{\text { ISO }}$ on 1 February 2007. (en.wikipe-dia.org.,).
Dardjowidjojo, 2003) berpen-dapat bahwa psiko-linguistik adalah studi tentang bahasa dan minda. ${ }^{3}$ Sejalan dengan pendapat ini, Field (2003) mengemukakan psycho-linguisttics explores the relationship between the human mind and langu-age and isquo (psikolinguistik membahas hubungan antara otak manusia dengan bahasa dan isquo). Minda beroperasi ketika terjadi pemakaian bahasa. Karena itu, Harley berpendapat bahwa psiko-linguistik adalah studi tentang proses mental dalam pemakaian bahasa. Sebelum menggunakan bahasa, seo-rang pemakai bahasa terlebih dahulu memperoleh bahasa. ${ }^{4}$ Dalam kaitan ini Levelt (dalam Marat, 1983) mengemukakan bahwa Psikolinguis-tik adalah suatu studi mengenai penggunaan dan perolehan bahasa oleh manusia. Kridalaksana (1984) pun berpendapat sama bahwa psiko-linguistik adalah ilmu yang mempe-lajari hubungan antara bahasa de-ngan perilaku dan akal budi manusia serta kemampuan berbahasa dapat diperoleh. ${ }^{5}$ Dalam proses berbahasa terjadi proses memahami dan menghasilkan ujaran, berupa aneka kalimat.

Karena itu, Emmon Bach (dalam Tarigan, 1985) mengeks-presikan bahwa Psikolinguistik ada-lah suatu ilmu yang

${ }^{3}$ Minda adalah suatu entiti yang berbeza daripada otak. Ia adalah suatu bentuk tenaga bukan organ. Menurut Bechtel (1988), minda melibatkan keselu-ruhan daripada fikiran, tanggapan, persepsi, memori, mimpi dan sebagainya. Minda juga dapat ditakrifkan sebagai keupayaan kognitif seperti kebolehan berfikir dan menaakul. Menaakul ialah kebolehan seseorang mem-buat pertimbangan ataupun keputusan dalam keadaan tertentu. (Azizi Yahaya, et.al., Aplikasi Kognitif dalam pendidikan, PTS professional, 2006).

${ }^{4}$ Soenjono Dardjowodjojo, Psiko-linguistik: Pengantar Pemahaman Bahasa Manusia, Jakarta: Yayasan Pustaka Obor Indonesia, 2003, Cet.ke-1, hlm. 7

${ }^{5}$ Harimukti Kridalaksana, Kamus Linguistik, Jakarta: Gramedia, 1984, Cet.ke-2, hlm. 140 
meneliti bagaimana sebenarnya para pembi-cara (pemakai) bahasa membentuk (membangun) varian kalimat bahasa tersebut. ${ }^{6}$ Sejalan dengan pendapat di atas Slobin dalam Chaer mengemu-kakan bahwa psikolinguistik men-coba menguraikan proses psikologi yang berlangsung jika seseorang mengucapkan nuansa kalimat yang didengarnya pada waktu berkomuni-kasi dan bagaimana kemampuan bahasa diperoleh manu-sia. ${ }^{7}$ Lebih jauh ditegaskan bahwa gagasan munculnya psikolinguistik sebenar-nya sudah ada sejak tahun 1952, yaitu sejak Social Science Research Council di Amerika Serikat mengundang tiga orang linguis dan psikolog untuk mengadakan konfe-rensi inter-disipliner. ${ }^{8}$ Secara formal terminologi psikolinguistik diguna-kan sejak tahun 1954 oleh Charles E. Osgood dan Thomas A. Sebeok dalam karyanya berjudul Psycho-linguistics: $A$ Survey of Theory and Research Problems. Sejak itu istilah tersebut sering digunakan. Selanjut-nya psikolinguistik merupakan inter-disiplin antara linguistik ${ }^{9}$ dan psikologi. ${ }^{1}$ Karena itu, dalam ${ }^{0}$ membahas pengertian psikolinguistik, terlebih dahulu penulis akan mengacu kepada pengertian kedua disiplin ilmu ter-sebut.

${ }^{6}$ Henry Guntur Tarigan, Psiko-linguistik, Jakarta: Angkasa Utama, 1985, Cet.Ke-1, hlm. 3

${ }^{7}$ Abdul Chaer, Psikolinguistik: Kaji-an Teoretik, Jakarta: PT Rineka Cipta, 2003, Cet.ke1 , hlm. 5

${ }^{8}$ Iis Lisnawati, Psikolinguistik Dalam Pembelajaran Bahasa, EDUCARE: Jurnal Pendidikan dan Budaya, Program Studi Pendidikan Bahasa dan Sastra Indonesia Fakultas Keguruan dan Ilmu Pendidikan Universitas Siliwangi Tasikmalaya, hlm. 2

${ }^{9}$ Linguistik (Ilm al-Lughah) adalah ilmu yang mengkaji tentang studi bahasa secara ilmiah. (Fatimah Mahjub, Dirasat Fi Ilm al-Lughah, alQahirah: Dar al-Nahdhah al-Arabiyah, tt., hlm. v).

${ }^{1}$ Psychology is the science $8 \mathrm{f}$ beha-vior and mind, embracing all aspects of conscious and unconscious experience as well as thought. It is an academic discipline and a social science which seeks to under-stand individuals and groups by establishing general principles and researching specific cases. (en.wikipedia.org., Psychology.).
Mencermati paparan di atas, maka ada tiga persoalan mendasar yang menjadikan penulis tertarik untuk mengkaji keterkaitan dua bi-dang disiplin ilmu ini, pertama: bahasa Arab secara historis memang bahasa yang sudah cukup tua di du-nia ini, akan tetapi perkembangan sektor kebahasaannya sangat pesat dan selalu update; kedua: Psikoli-nguistik adalah gabungan/ konvergensi dua bidang disiplin ilmu, yaitu ilmu psikologi dan linguistik meru-pakan disiplin ilmu baru bagi uni-versitas yang memiliki fakultas dan jurusan bahasa untuk mengaktua-lisasikan disiplin ilmu ini secara maksimal; ketiga: mengkaji relevansi bahasa Arab dan psikolinguistik se-cara historis dan konseptual sangat menarik dan urgen, karena akan memunculkan temuan baru yang sangat bermanfa'at bagi pembaca. Ketiga persoalan substansial inilah merupa-kan urgensitas penelitian ini dihadir-kan. Sebagai bahan komparasi dan keunikan penelitian ini, maka pene-liti menghadirkan beberapa hasil kajian terdahulu yang relevan berikut ini.

Mochamad Isma'il (2013) telah menulis tentang "Peran Psiko-linguistik dalam Pembelajaran Ba-hasa Arab", dengan simpulan bahwa pengertian psikolinguistik berdasar-kan ruang lingkupnya adalah ilmu yang mempelajari aktivitas berba-hasa manusia, baik pemerolehan, pemahaman, dan penggunaan baha-sa. Sedangkan pembelajaran bahasa Arab adalah bidang yang membahas teori, metode, teknik untuk memberi kemampuan kompetensi bahasa (mendengar, berbicara, membaca, menulis) bahasa tujuan kepada pela-jar. Baik psikolinguistik maupun pembelajaran bahasa Arab, keduanya mempunyai bidang kajian yang sama yaitu bahasa. Di samping itu kedua-nya juga termasuk linguistik terapan (applied linguistics), sehingga ke-duanya mempunyai kaitan yang sa-ngat erat. Maka seorang pendidik di samping harus 
menguasai prinsip pendidikan, ia juga dituntut mengerti aneka prinsip psikologi dan linguis-tik yang merupakan kajian psiko-linguistik. Di dalam kurikulum pendidikan bahasa pada lembaga pendi-dikan tenaga kependidikan, mata kuliah psikolinguistik dimasukkan dalam kelompok mata kuliah proses pembelajaran, dan bukan pada ke-lompok mata kuliah linguistik (keba-hasaan). Konteks ini menandakan besarnya peranan ilmu psikoli-nguistik dalam pembelajaran baha-sa Arab. Selanjutnya persamaan kaji-an terdahulu dengan kajian yang se-dang berlangsung adalah sama-sama mengkaji aspek psikolinguistik, se-mentara perbedaan yang tampak ada-lah kajian terdahulu mengkaji aspek peranan psikolinguistik dalam pem-belajaran bahasa Arab. Sedangkan kajian saat ini akan menelisik aspek relevansi bahasa Arab dan psikolinguistik: kajian konseptual dan his-toris.

Selanjutnya, dalam tahun yang sama (2013) Achmad Fuad Hasyim telah telah menulis karya ilmiah tentang "Terminologi Psikolinguis-tik" dengan simpulan bahwa Psiko-linguistik adalah ilmu yang mem-pelajari aneka proses mental yang dilalui oleh manusia dalam rangka berbahasa. Di sisi lain, psikolinguistik juga empat dimensi substansial, yaitu: komprehensi; pro-duksi; landasan biologis dan neuro-logis yang membuat manusia bisa berbahasa; serta pemerolehan baha-sa. Sementara psikolinguistik - se-cara historis-berawal dari eksisnya pakar linguistik yang berkecen-derungan pada psikologi, di sam-ping adanya pakar psikologi yang berkecimpung dalam sektor li-nguistik. Kemudian dilanjutkan dengan kerja sama antara pakar linguistik dan psikologi, yang melahirkan pakar psikolinguistik se-bagai disiplin ilmu tersendiri. Se-dangkan perkembangan ilmu psiko-linguistik diklasifikasikan pada empat tahap, yaitu: tahap formatif; tahap linguistik; tahap kognitif; dan tahap teori psikolinguistik, rea-lita psikologis, dan ilmu kognitif. Adapun aneka kajian yang menji-wai lingkupan psikolinguistik itu sendiri adalah: proses bahasa da-lam komunikasi dan pikiran; peme-rolehan bahasa; pola tingkah laku berbahasa; asosiasi verbal dan per-soalan makna; proses bahasa pada orang yang abnormal; serta persep-si, ujaran dan kognisi. Persamaan studi terdahulu dengan studi yang sedang berlangsung adalah sama-sama membahas substansi psiko-linguistik, sementara perbedaan yang tampak adalah studi terdahulu meng-kaji terminologi psikolinguistik, se-dangkan studi saat ini akan mema-parkan bahasa Arab dan psiko-linguistik: kajian konseptual dan his-toris.

Adapun Shafa (2014) telah menulis karya ilmiah tentang "Teori Pemerolehan Bahasa dan Implikasi-nya dalam Pembelajaran" dengan simpulan bahwa Tipe Naturalistik adalah tipe yang paling banyak dijumpai dalam pemerolehan bahasa kedua. Term ini, dikarenakan manu-sia sebagai makhluk sosial yang menyatu dengan lingkungan sekitar. Terlebih lingkungan heterogen sangat berpengaruh terhadap pemero-lehan bahasa kedua--baik orang dewasa maupun anak-anak. Sedang-kan tipe formal, cara pemerolehan bahasanya kurang bisa memuaskan. Term ini disebabkan oleh disiplin pendidik dan pembelajar kurang maksimal, sehingga hasilnya pun sama. Di sisi lain, ada empat faktor yang mempengaruhi pemerolehan bahasa kedua anak manusia, yaitu faktor 
motivasi, usia, penyajian formal dan faktor bahasa pertama pembelajar. Sementara dari keempat faktor dimaksud, pemerolehan baha-sa kedua dipengaruhi oleh faktor internal dan faktor eksternal diri pembelajar. Faktor internal adalah faktor mativasi dan faktor usia. Sedangkan faktor eksternal merupakan faktor penyajian formal, yaitu faktor guru, materi pembe-lajaran, media dan metode pem-belajaran yang tepat, di samping faktor kesiapan, kualitas, dan mo-tivasi guru. Persamaan kajian ter-dahulu dengan kajian yang sedang berlangsung adalah sama-sama mem-bahas studi psikolinguistik, semen-tara perbedaan yang tampak adalah kajian terdahulu mengkaji teori pemerolehan bahasa dan implikasi-nya dalam pembelajaran, sedangkan kajian saat ini akan memaparkan bahasa Arab dan psikolinguistik: kajian konseptual dan historis.

\section{LANDASAN TEORI}

Mencermati paparan di atas, maka minimal ada dua opsi yang dapat dijadikan sebagai landasan teori penelitian ini. Pertama, kajian konseptual bahasa Arab; dan kedua, historis psikolinguistik itu sendiri. Opsi pertama, bahwa Bahasa arab adalah bahasa yang di gunakan secara luas di bumi ini. Bahkan Ba-hasa arab merupakan bahasa utama dari 22 negara, dan merupakan bahasa peribadatan dalam agama islam karna merupakan bahasa yang di pakai oleh Al-
Qur'an. Digunakan oleh lebih dari 250 juta orang di dunia. Bahasa ini juga merupakan bahasa kedua pada negaranegara islam karena di anggap sebagai bahasa spiritual islam - salah satu agamaagama besar dunia (kita membicarakan tentang lebih dari 1 miliar orang). bahasa arab merupa-kan bahasa tetap di organisasi perserikatan baangsa-bangsa (PBB). Alasan lain yaitu bahasa arab yaitu bahasa tertua yang hidup di dunia (diriwayatkan nabi adam AS pun memakai bahasa arab selain beliau juga mengerti semua bahasa di dunia), bahkan ada teori mangatakan bahwa "bahasa arab merupakan asal dari bahasa-bahasa" dan mereka yang mengadopsi teori ini berlandaskan pada kenyataan bahwa orang Arab dapat melafalkan sara apapun dalam bahasa manapun di dunia dengan mudah, di lain pihak banyak orang-orang bukan arab yang kesu-litan mengucapkan beberapa huruf Arab yang tidak terpakai dalam bahasa asli mereka (contohnya huruf dhad tidak digunakan dalam bahasa manapun di dunia, dan bahasa arab sering disebut bahasa dhad).

Sementara opsi kedua, adalah psikolinguistik yang merupakan konvergensi antara dua disiplin ilmu (psikologi dan linguistik), sehingga secara definitif psikolinguistik adalah studi tentang faktor-faktor psikis dan genetika fital yang memungkinkan manusia untuk memperoleh, meng-gunakan, memahami dan mempro-duk suatu bahasa. ${ }^{1}$ Dengan demi-kian dapat dipahami bahwa psiko-

${ }^{1}$ Shaleh Bal'id, Ilm al-Lughtah al-Nafsi, Revue Campus, No. 10, hlm. 65. Psikolinguistik ini juga merupakan salah cabang terpenting dari disiplin ilmu linguistik terapan yang sangat concern terhadap studi bahasa, pemerolehannya, penggunaannya dan pemahamannnya. (Majallah al-Jami'ah al-Islamiyah, Volume 154, hlm. 505). 
linguistik secara subsatnsial adalah mengkaji fungsi bahasa dan fungsi akal manusia, sehingga mereka dapat menggunakannya, memamahaminya dan bahkan memproduknya. Psiko-linguistik ini mengacu kepada prin-sip falsafat. Psinsip ini juga mengacu kepada data yang saling terkait seputar tatacara akal manusia ber-aksi.

\section{METODE PENELITIAN}

Penelitian ini merupakan studi kepustakaan (library research) de-ngan cara menela'ah aneka literatur yang berkaitan dengan "Bahasa Arab dan Psikolinguistik: Kajian Konsep-tual dan Historis", terutama literatur yang ditulis oleh para pakar bahasa Arab dan psikolinguistik. Sedangkan metode yang akan dite-rapkan dalam penelitian ini adalah deskriptif dan analisis. Kedua meto-de ini tidak diterapkan satu persatu, akan tetapi diterapkan secara seren-tak. Metode deskripsif dipakai, karena dalam uraiannya akan mem-berikan gam-baran umum tentang persoalan yang akan dikaji, kemu-dian dari data tersebut akan diadakan interpretasi. Sementara metode anali-sis diguna-kan untuk melihat secara kritis berbagai persoalan yang melatar belakangi persoalan tersebut. Untuk prosedur pengolahan data, digunakan Content Analysis.

\section{HASIL DAN PEMBAHASAN}

Dalam hasil dan pembahasan data ini akan ditelisik dan dipaparkan secara cermat tentang konseptual bahasa Arab dan historis psiko-linguistik. Paparan detail sta-tement di atas, dapat dicermati secara kritis berikut ini.

\section{Konseptual Bahasa Arab}

Bahasa Arab memiliki kedu-dukan penting bagi umat Islam. Bahasa Arab merupakan salah satu bahasa internasional, ${ }^{1}$ di samping bahảsa Prancis, Spanyol, Cina, dan Inggris. Bahasa Arab juga menjadi salah satu bahasa resmi Perserikatan BangsaBangsa. Lebih dari satu miliar Muslim berdoa dan beribadah dengan bahasa ini setiap harinya. Menurut Ethnologue, bahasa Arab merupakan bahasa berpenutur asli nomor lima terbanyak di dunia dengan 242,391 juta jiwa di 60 (enam puluh) negara. Bahasa Arab merupakan bahasa nasional di 25 (dua puluh lima) negara, seperti Arab Saudi, Algeria, Bahrain, Chad, Kamerun, Djibouti, Mesir, Irak, Israel, Yordania, Kuwait, Lebanon, Libya, Maroko, Mauritania, Oman, Palestina, Qatar, Somalia, Sudan, Suriah, Tunisia, Uni Emirat, dan Yaman.

Ada banyak teori tentang asal usul bahasa ini. ${ }^{1}$ Sebagian pendapat meng-

${ }^{1}$ Bahasa Arab sebagai salah ${ }^{2}$ satu bahasa internasional, juga telah menjadi bahasa agama yang pada gilirannya menjadi bahasa pemersatu bagi umat Islam dengan melalui proses yang panjang. Bahasa Arab juga memiliki fungsi istimewa dari bahasa-bahasa lainnya, bukan saja bahasa Arab memiliki nilai sastra bermutu tinggi bagi mereka yang mengetahui dan mendalami, akan tetapi bahasa Arab ditakdirkan sebagai bahasa al-Qur'an yakni mengko-munikasikan kalam Allah yang di dalamnya mengandung uslub bahasa yang sungguh mengagumkan manusia. (Asal-Usul Bahasa Arab, Makalah Ilmiah), 22 Desember 2016, di akses, 24 Mei 2017.

${ }^{1}$ Sejak bahasa Arab yang tertua dalam alQur'an digunakan hingga kini, semua pengamat 
ekspresikan, bahwa bahasa Arab telah ada semenjak Nabi Adam. Hal ini merupakan interpretasi al-Qur'an surah al-Baqarah ayat 31 bahwa Allah telah mengajarkan pengetahuan tentang nama-nama kepada Nabi Adam. Bahasa yang digunakan oleh Adam tersebut ditafsirkan sebagai bahasa Arab. Jadi, bahasa ini merupakan bahasa pertama yang diguna-kan manusia, kemudian berkembang menjadi ber-bagai cabang baru. Pendapat kedua mengatakan, bahasa Arab termasuk rumpun bahasa Semetik $^{1}$ yang merupakan ${ }^{4}$ turunan rumpun Afroa-siatik. Menurut para ahli modern, bahasa di dunia awalnya berasal dari daerah asal mula manusia pertama me-netap, yaitu sekitar Asia dan Afrika. Bahasa yang lahir dari kawasan ini pada masa-masa beri-kutnya mencapai ratusan

baik Barat maupun muslim Arab menganggapnya sebagai bahasa yang memiliki standar ketinggian dan keelokan lingguistik yang tertinggi yang tiada taranya (the supremen standar of linguistic excelence and beauty) dan hal ini berdampak pada munculnya sprioritas sastra, Terutama setelah pemikir-pemikir Barat (khusus melakukan kajiankajian ketimuran, yang biasa disebut orientalis) mulai mengemukakan pemikirannya terhadap Islam.Tentu saja dengan beragam motif mempelajarinya, maka usaha-usaha untuk mempermudah mempelajari dan mempublikasikan sebagai bahasa asing dari luar mulai digunakan. (Harun Ar-Rasyid, Prospek Bahasa Arab masa kini dan masa yang akan datang, Makalah Seminar Himpunan Mahapeserta didik Jurusan Pendidikan Bahasa Arab, HMJ-PBA).

${ }^{1}$ Seorang sarjana ahli băhasa yang terkenal, A. L. Schioser (wafat tahun $1781 \mathrm{M}$ ) menjelaskan bahasa Arab adalah termasuk rumpun bahasa semit dan menjelan abad ketiga Masehi, bahasa Arab berkembang menjadi bahasa yang sempurna. Melacak asal usul bahasa Arab, partum-buhan dan pembagianya secara jelas dapat dilihat bahwa bahasa Arab mengalami kemunduran dengan banyaknya bahasa Arab (dialek) yang telah punah dan hanya dapat diketahui melalui pahatan-pahatan atau lebih dikenal dengan al-Arabiyah al-Nuqusy (Abdullah Abbas al-Nadawi, Learen the Language of the Holy Qur'an, diter-jemahkan oleh tim redaksi penerbit Mizan dengan judul, Belajar Mudah Bahasa al-Qur'an, Kairo: Dar al-Marifah, Cet.ke2, hlm. 35). bentuk bahasa baru yang digunakan oleh sebagian besar penduduk dunia.

Bahasa ini dinamakan Afro-Asiatic atau Afrasian atau Hamito Semitic, sebuah istilah yang diper-kenalkan oleh Mau-rice Delafosse (1914). Bahasa ini memperanakkan sekitar 400 (empat ratus) jenis bahasa yang beberapa di antaranya telah punah. Salah satunya, adalah rumpun bahasa Semit yang menjadi tempat bernaung bahasa Arab dalam pohon klasifikasi bahasa. Kata Semit diambil dari Sem (Syam) putra Nuh, nenek moyang Ibrahim dan Ismail. Rumpun bahasa ini diperkirakan telah ada di Timur Tengah sejak abad keempat Sebelum Masehi, kemudian berkembang masuk ke kebudayaan Mesopotamia dan men-capai Suriah. Rumpun ini juga menurunkan ba-hasa Akkadian (telah punah), Ibrani, dan Aramaik yang banyak digunakan dalam literatur-literatur kuno. Abd Rauf bin Dato' Hassan Azhari dalam "Sejarah dan Asal Usul Bahasa Arab: Satu Kajian Linguistik Sejarawi", Pertanika Journal of Soc Sci and Hum 2004, menguatkan pendapat tersebut. "Jika dianalisis dari segi konteks klausa, ternyata banyak terdapat titik kesamaan antara bahasa Semit dan bahasa Arab kuno," kata dia. Con-tohnya, dalam unsur fonologi, unsur-unsur fleksi (al-I'rab), dan pola bentuk jamak. Penelitian menunjuk-kan, bahasa Arab juga memiliki banyak kesamaan dengan bahasa Ibrani, sesama rum-pun Semit.

${ }^{1}$ Bahasa Arab menurut para linguistik berasal dari ras manusia dan rumpun bangsa yang mempunyai peran besar dalam sejarah peradaban kuno yakni bahasa Semit kemudian keturunan mereka berpindah tempat meninggalkan tanah airnya dan menetap di lembah sungai Tigris dan Euphart sehingga membentuk rumpun bahasa dan bangsa baru. Termasuk di dalamnya bahasa Ibrani. Pergumulan antar bahasa, saling berinteraksi dan mendomi-nasi. Oleh karena itu Max Muller dan Bunsen mengelompokkan bahasa menjadi 3 rumpun yaitu: rumpun bahasa Indo-Eropa, Semit, dan Turania. Lihat Jurji Zaidan, Tarikh al-Lughah al-Arabiyah, Cairo: Dar al-Ma'arif, 1977, hlm. 21). 
Lebih jauh dipaparkan bahwa perkembangan bahasa Semit, mun-cullah bangsa Akkadia yang meru-pakan rumpun bangsa Semit, bah-kan dianggap sebagai bangsa dan bahasa yang tertua dari rumpun Semit yang terditeksi dalam catatan sejarah. Bangsa ini mendiami wila-yah lembah sungai Tigris Euphrat yang lebih dikenal dengan Mesopotamia kira-kira 3000 tahun SM. Kata Akkadia berasal dari nama Ibukota Akkad. ${ }^{1}$ Bangsa Akkadia biasa pula disebut dengan bangsa Babilonia dan Assuriyah, ${ }^{1}$ kedua bangsa tersebut mempergunakan bahasa Akka-dia. Bahasa Aramiyah dan bahasa Kan'aniyah dipergunakan oleh bangsa Finikiyah dan Arabiyyah dan selanjutnya muncul pula bahasa Arab, bahasa Yaman kuno, dan bahasa Habsyi. ${ }^{1}$ Dengan demikian, ${ }^{8}$ tidaklah meng-herankan jika terlihat adanya persamaan-persamaan dalam bahasa mereka. Hanya saja menurut para peneliti, ${ }^{1}$ sangat sulit untuk dibuktikan karena kita tidak menge-tahui bahasa-bahasa yang telah disebutkan sebelumnya kecuali ter-batas pada bahasa Arab saja.

Di antara sekian rumpun bahasa Semit yang telah dikemuka-kan bahwa semuanya telah punah ditelan oleh dinamika perjalanan umat manusia yang telah melewati ribuan tahun, ${ }^{2}$ yang tersisa hanyalah bahasa Arab yang sekaligus memberi pengaruh yang cukup besar dalam sejarah peradaban umat

${ }^{1}$ Anwar G. Ghejne, The Arabic Language Its Role In History, diterje-mahkan oleh Aliuddin Mahjuddin dengan judul Bahasa arab dengan Peranannya dalam Sejarah, Jakarta: Pusat Pembinaan dan Pengembangan Bahasa Departemen Pendidikan dan Kebudayaan, 1996, hlm. 29

${ }^{1}$ Ali Abd. al-Wahidwafi, Fiqh al-Lughah, Beirut: Dar al-Fikr, Cet.ke-7, hlm. 201

${ }^{1}$ Ali abd. al-Wahid Wafi, Ibid. ${ }^{8}$

${ }^{1}$ Muhammad Sagena, Analisis Fiqh alLughah terhadap Asal Usul Bahasa Arab, Penelitian IAIN Alauddin Makassar, 1998, hlm. 67

${ }^{2}$ George Zaidan, al-Falsafah al-Lughah, Bairut: Dar al-Jil, 1987, Cet.ke-3, hlm. 26-29 manusia, terutama disaat memasuki abad ke-6 Masehi. Sejarah menunjukan, bahwa proses bahasa Arab menjadi suatu bahasa yang berdiri sendiri melalui proses yang cukup lama. Proses pertama, dengan pemi-sahan salah satu keturunan bangsa Semit yang mengembara ke wilayah jazirah yang bertujuan untuk memperluas wilayah kekuasaan. ${ }^{2}$ Proses kedua, terbentuknya kebuda-yaan lain yang sudah berbeda defigan bangsa per-tama yang akhirnya tercipta alat komunikasi yang tampak berbeda dengan bahasa aslinya.

Jika kembali kepada sejarah pembentukan bahasa maka akan dikemukakan suatu proses yang sangat panjang selama berabad-abad. Kata yang satu mungkin saja tidak terpakai lagi dan selanjutnya hilang dan digantikan oleh kata baru, seperti halnya kita di Indonesia apakah itu serapan atau terbentuk dari proses perbe̊daan dialek di antara bangsa atau suku penutur bahasa Arab. Sebagai hasil proses perkembangan bahasa maka dapat dilihat kekuatan bahasa Arab Fusha yang berkembang hingga sekarang ini.

Sebagaimana dipaparkan sebelumnya, bahwa bahasa Arab adalah salah satu bahasa yang termasuk rumpun bahasa Semit yang berdiam di sebelah selatan, tepatnya di wi-layah $\mathrm{Irak}^{2}$ dengan demikian, hu-bungan antara bahasa Arab dan Semit sangat kuat. Untuk dapat mengetahui bahasa Arab sebelum datangnya agama Kristen, para peneliti tidak dapat menemukan gambaran yang jelas, karena tidak ada bukti dokumentasi yang tertulis berupa teksteks yang bisa diperoleh pada masa tersebut. Teks tertua yang ditemukan adalah sesudah abad ke III Masehi. ${ }^{2}$

11

${ }^{2}$ Ali Abd Wahid Wafi, Op. Cit., hlm. 10-

${ }^{2}$ Ibid, hlm. 96

${ }^{2}$ Mulianto Sumardi, et.al., ${ }^{3}$ Pedoman Pengajaran Bahasa Arab pada Perguruan Tinggi Agama Islam IAIN (Jakarta: Proyek 
Akibat kelangkaan teks-teks Arab telah menyebabkan meluasnya buta huruf (ummiyah) di kalangan bangsa Arab sebelum datangnya Islam. Menurut Ali Abd al-Wahid Wafi, informasi yang sempat terekam dalam sejarah dan sampai kepada kita tentang sejarah bahasa Arab adalah temuan dari prasasti tentang Arab Baidah yang diperkirakan hidup pada abad pertama sebelum masehi, sedangkan Arab Baqiyah infor-masi yang ditemukan nanti setelah abad kelima masehi. Sehingga periodesasi par-tumbuhan bahasa Arab sangat sulit untuk dilacak. ${ }^{2}$

Hal yang senada dikemukakan oleh Anwar G. Chejne, bahwa data bahasa Arab secara tertulis masih sangat sedikit jika dibandingkan dengan bahasa-bahasa lain, ${ }^{2}$ sehing-ga periodesasi Bahasa Arab dan kesusastraannya hanya terbatas pada masa jahiliyah, masa munculnya Islam yang dibawa oleh Muhammad Saw, masa Khulafa' al-Rasyidun, bani Umaiyah, bani Ab-basiyah, dan periode Modern. ${ }^{2}$ Adapun yang diperpegangi para ahli, tentang perkem-bangan bahasa Arab pada masa pra Islam (jahiliyah) adalah nukilan puisi-puisi yang dikembang-kan pada zaman tersebut yang dipindahkan dari generasi-kegenerasi selanjutnya. ${ }^{2}$ Dalam pembagian ba-hasa Arab terbagi dua kelompok besar yaitu; Arab Baidah dan Arab Baqiyah.

\section{Historisitas Psikolinguistik}

Psikolinguistik merupakan il-mu hibrida, ${ }^{2}$ yaitu ilmu yang meru-pakan

Pengembangan Sistem Pendidikan RI, 1976, hlm. 30-31

${ }^{2}$ Ali Abd. Wahid Wafi, Op. Clt., hlm. 97

2 Anwar G. Chejne, Op. Cit, hlim. 39

${ }^{2}$ Mulianto Sumardi, Op.Cit., hlm. 34. bandingkan dengan Broklama, Tarikh al-Adab alAraby, Jilid-1, al-Qahirah: Dar al-Maarif, Tanpa tahun, Cet.ke-4, hlm. 36

${ }^{2}$ Muhammad Suyuti Suhaib, Kajian Puisi Arab Pra Islam, Jakarta: al-Qushwa, 1990, Cet. ke-1, hlm. 2

${ }^{2}$ Hibrida adalah Bio turunan yang dihasilkan dari perkawinan antara dua jenis yang gabungan antara dua ilmu, yaitu psikologi dan linguistik. Benih ilmu ini sebenarnya sudah tampak pada permulaan abad ke-20 tatkalan psikolog Jerman Wilhem Wundt menyatakan bahwa bahasa dapat dijelaskan dengan dasar prinsip-prinsip psikologis (Kess, 1992). Pada waktu itu telaah bahasa mulai mengalami perubahan dari sifatnya yang estetik dan kultural ke suatu pendekatan yang "ilmiah". Sementara itu di benua Amerika kaitan antara bahasa dengan ilmu jiwa juga mulai tumbuh. Perkembangan ini dapat dibagi menjadi empat ${ }^{4}$ tahap, yaitu tahap formatif, tahap linguistik, tahap kognitif, dan tahap teori psikolinguistik, realita, dan ilmu kognitif.

\section{a. Tahap Formatif}

Pertengahan abad kedua puluh John W. Gardner, seorang psikolog dari Carnegie Corporation, Amerika, mulai menggagas hibridisasi (peng-gabungan) kedua ilmu ini. Ide ini kemudian dikembangkan oleh́ psiko-log lain, John B. Carrol, yang pada tahun 1951 menyelenggarakan semi-nar di Universitas Cornell untuk merintis keterkaitan antara kedua disiplin ilmu ini. Pertemuan itu dilanjutkan pada tahun 1953 di ${ }^{7}$ Uni-versitas Indiana. Hasil pertemuan ini membuat gema yang begitu kuat di antara para ahli ilmu jiwa maupun ahli bahasa sehingga banyak penelitian yang kemudian dilakukan terarah pada kaitan antara kedua ilmu ini. Pada saat itulah istilah psycho-linguistics pertama kali dipakai. Kelompok ini mendukung penelitian mengenai relativitas bahasa maupun universal bahasa. Pandangan tentang relativitas bahasa seperti dikemuka-kan oleh Benjamin Lee Whorf $(1956)^{2}$ dan universal bahasa seperti

berlainan (tentang hewan atau tum-buhan). Contoh: Psikolinguistik meru-pakan gabungan dari dua disiplin ilmu, yaitu Psikologi dan Linguistik.

${ }^{2}$ Benjamin Lee Whorf, April 24, 1897-July 26, 1941) was an American linguist and fire prevention engineer. Whorf is widely known as an 
dalam karya Greenberg (1963) ${ }^{3}$ merupakan karya-karya pertama da-lam bidang psikolinguistik.

\section{b. Tahap Linguistik}

Perkembangan ilmu linguistik yang semula berorientasi pada aliran behaviorisme dan kemudian beralih ke mentalisme pada tahun 1957 dengan diterbit-kannya buku Chom-sky, Syntactic Structures, dan kritik tajam dari Chomsky terhadap beha-vioristik B.F. Skinner telah membuat psikolinguistik seba-gai ilmu yang banyak diminati orang. Hal ini semakin berkembang karena pan-dangan Chomsky $^{3}$ tentang universal bahasa,

advocate for the idea that differences between the structures of different languages shape how their speakers perceive and conceptualize the world. This principle has frequently been called the "Sapir-Whorf hypothesis", after him and his mentor Edward Sapir, but Whorf called it the principle of linguistic relativity, because he saw the idea as having implications similar to Einstein's principle of physical relativity. (Wikipedia.org).

3 Joseph Harold Greenberg (May 28, 1915May 7, 2001) was an American linguist, principally known for his work in two areas, linguistic typology and the genetic classification of languages. Green-berg's reputation rests in part on his contributions to synchronic linguistics and the quest to identify linguistic universals. In the late 1950s, Greenberg began to examine corpora of languages covering a wide geographic and genetic distribution. He located a number of interesting potential universals as well as many strong cross-linguistic tendencies. In particular, Green-berg conceptualized the idea of "implicational universal", which takes the form, "if a language has structure $\mathrm{X}$, then it must also have structure Y." For example, X might be "mid front rounded vowels" and $\mathrm{Y}$ "high front rounded vowels" (for termi-nology see phonetics). Many scholars took up this kind of research following Green-berg's example and it remains important in synchronic linguistics. Like Noam Chom-sky, Greenberg sought to discover the universal structures underlying human language. (Wikipedia.org).

${ }^{3}$ Avram Noam Chomsky ${ }^{1}$ was born December 7, 1928) is an American linguist, philosopher, cognitive scientist, historian, social critic, and political activist. Some-times described as "the father of modern linguistics", Chomsky is also a major figure in analytic philosophy and one khususnya pertanyaan "me-ngapa anak di manapun juga mem-peroleh bahasa mereka dengan memakai strategi yang sama". Kesa-maan dalam strategi ini didukung juga oleh berkembangnya ilmu neurolinguistik dan biolinguistik. Studi dalam neurolinguistik ${ }^{3}$ me-nunjukkan bahwa manusia ditak-dirkan memiliki otak yang berbeda dengan primata lain, baik dalam struktur maupun fungsinya. Pada manusia ada bagian-bagian otak yang dikhususkan untuk kebahasaan, sedangkan pada binatang bagian-bagian ini tidak ada. Dari segi bio-logi manusia juga ditakdirkan memi-liki struktur biologi yang berbeda dengan binatang.

Keterkaitan neurobiologi mendukung pandangan Chomsky yang mengatakan bahsa pertumbuhan ba-hasa pada manusia terprogram secara genetik. Orang telah banyak mela-kukan penelitian

of the founders of the field of cognitive science. $\mathrm{He}$ is Institute Professor Emeritus at the Massachusetts Institute of Technology (MIT), where he has worked since 1955, and is the author of over 100 books on topics such as linguistics, war, politics, and mass media. From 1951 to 1955 he was appointed to Harvard University's Society of Fellows, where he developed the theory of trans-formational grammar for which he was awarded his doctorate in 1955. That year he began teaching at MIT, in 1957 emerging as a significant figure in the field of linguistics for his landmark work Syntactic Structures, which remodeled the scientific study of language, while from 1958 to 1959 he was a National Science Foundation fellow at the Institute for Advanced Study. He is credited as the creator or co-creator of the universal grammar theory, the generative grammar theory, the Chomsky hierarchy, and the minimalist program. Chomsky also played a pivotal role in the decline of behaviorism, being particularly critical of the work of B. F. Skinner. (Wikipedia.org).

${ }^{3}$ Neurolinguistik adalah salah ${ }^{2}$ satu bidang

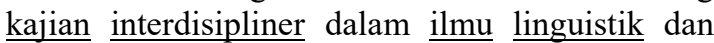
ilmu kedokteran yang mengkaji hubungan antara otak manusia dengan bahasa. Gangguan pada kemampuan berbahasa karena kerusakan otak

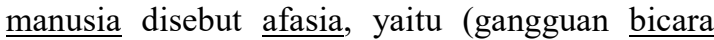
karena mengalami gegar/trauma otak). Orang yang menderita kerusakan bahasa ini dapat diamati dari ketidakmampuannya berbahasa secara normal. (Wikipedia.org). 
dan mencoba me-ngajar binatang untuk berbahasa, tetapi tidak satu pun dari mereka yang berhasil. Ketidak berhasilan semua penelitian ini membuktikan bahsa pemerolehan bahasa adalah unik untuk manusia.

\section{c. Tahap Kognitif}

Pada tahap ini psikolinguistik mulai mengarah pada peran kognisi dan landasan biologis manusia dalam pemerolehan bahasa. Pelopor seperti Chomsky mengatakan bahwa linguis itu sebenarnya adalah psikolog kog-nitif. ${ }^{3}$ pmerolehan bahasa pada manusia bukanlah penguasaan kom-ponen bahasa tanpa berlandas-kan pada beberapa prinsip kognitif. Tatabahasa, misalnaya, tidak lagi dipandang sebagai sesuatu yang terlepas dari kognisi manusia karena konstituen dalam suatu ujaran se-benarnya mencerminkan realita psi-kologi yang ada pada manusia tersebut. Ujaran bukanlah suatu uru-tan bunyi yang linear tetapi urutan bunyi yang membentuk unit-unit kons-tituen yang hierarkis dan masingmasing unit ini adalah realita psikologis. Frasa orang tua itu, misalnya, membentuk suatu kesatuan psikologis yang tidak dapat dipisah-kan. Frasa ini dapat diganti dengan hanya satu kata seperti Achmad atau dia.

Pada tahap ini orang juga mulai bicara tentang peran biologi pada bahasa karena mereka mulai merasa bahwa

${ }^{3}$ Psikologi kognitif, mempelajari, menalar, mengingat dan berpikir tentang suatu informasi. Kognitif dalam psikologi dapat berarti dua, yaitu bisa diartikan sebagai aktivitas mental (persepsi, memori, atensi, dll) dan juga dapat diartikan sebagai sebuah pendekatan psikologi. Sejarah dari psikologi kognitif berawal pada saat Plato (428348SM) dan muridnya Aristotle (384-322SM) memperdebatkan mengenai cara manusia memahami pengetahuan maupun dunia serta alamnya. Plato berpendapat bahwa manusia memperoleh pengetahuan dengan cara menalar secara logis, aliran ini disebut sebagai rasionalis. Lain halnya dengan Aristotle yang menganut paham empiris dan mempercayai bahwa manusia memperoleh pengetahuannya melalui bukti-bukti empiris. (Wikipedia.org). biologi merupakan landasan di mana bahasa itu tumbuh. Pakar linguis-tik seperti Chomsky dan Lennerberg mengatakan bahwa partumbuhan bahasa seorang manu-sia itu terkait secara genetik dengan pertumbuhan biologisnya.

\section{d. Tahap Teori Psikolinguistik}

Pada tahap akhir ini psikoli-nguistik tidak lagi berdiri sebagai ilmu yang terpisah dari ilmu-ilmu lain karena pemerolehan dan peng-gunaan bahasa manusia menyangkut banyak cabang ilmu pengełahuan yang lain. Psiko-linguistik tidak lagi terdiri atas psiko dan linguistik saja tetapi juga menyangkut ilmu-ilmu lain seperti neurologi, ${ }^{3}$ filsafat, primatologi, ${ }^{3}$ dan genetika. Neuro-logi mempunyai peran yang sangat erat dengan bahasa karena kemampuan manusia berbahasa ternyata bukan karena lingkungan tetapi karena kodrat neurologis yang diba-wanya sejak lahir. Tanpa otak dengan fungsi-fungsinya yang kita miliki seperti sekarang ini, mustahil manusia dapat ber-bahasa. Ilmu filsafat

${ }^{3}$ Neurologi adalah cabang ${ }^{4}$ dari ilmu kedokteran yang menangani kelainan pada sistem saraf. Dokter yang mengkhususkan dirinya pada bidang neurologi disebut neurolog dan memiliki kemampuan untuk mendiagnosis, merawat, dan memanejemen pasien dan kelainan saraf. Kebanyakan para neurolog dilatih untuk menangani pasien dewasa. Untuk anak-anak dilakukan oleh neurolog pediatrik, yang merupakan cabang dari pediatri atau ilmu kesehatan anak. Di Indonesia, dokter dengan spesialisasi neuro-logi diberi gelar Sp.S. atau Spesialis Saraf. (Wikipedia.org).

${ }^{3}$ Primatologi adalah cabang zoologi yang mempelajari kehidupan (biologi) primata selain manusia (kera, monyet, dan kerabatnya). Ilmu ini dianggap penting sekarang ini karena makin meningkatnya perhatian terhadap kelestarian hewan-hewan yang tergolong primata. Selain itu, ber-dasarkan DNA sekuensing diketahui bahwa komposisi genetik manusia dan sebagian primata tidak jauh berbeda (bahkan hingga lebih dari 99\% pada bonobo). Kaitan dengan memahami proses belajar. Prima-tologi dipelajari sebagai ilmu khusus pada bidang biologi atau kehutanan (terutama aspek konservasinya). Kedokteran hewan juga mempelajari ilmu ini pada tingkat lanjut. (Wikipedia.org). 
juga kem-bali memegang peran karena pemerolehan penge-tahuan merupakan masalah yang sudah dari jaman purba menjadi perdebatan di antara para filosof--apa pengetahuan dan bagaimana--manusia memperoleh pengeta-huan. Primatologi dan genetika mengkaji sampai seberapa jauh bahasa itu milik khusus manusia dan bagaimana genetika terkait dengan partum-buhan bahasa. Dengan kata lain, psikolinguistik kini telah menjadi ilmu yang ditopang oleh ilmu-ilmu lain.

Secara historis, ada beberapa tokoh linguistik, diantaranya yang mengkaji bahasa secara psikologi adalah Von Humbolt, ${ }^{3}$ Ferdinand de Salussure, Edward Sapir, Leonard Bloomfield, dan Otto Jespersen. Von Humbolt (17671835). Mereka meru-pakan ahli linguitik asal Jeman yang membandingkan gramatika antar bahasa yang berlainan dengan tabiat penutur bahasa. Hasil penelitiannya menjelaskan bahwa gramatika suatu bangsa menunjukkan pandangan hidup bangsa tersebut. Von Humbolt sangat dipengaruhi aliran

${ }^{3}$ Friedrich Wilhelm Chrfstian Karl Ferdinand von Humboldt (22 June 1767-8 April 1835) was a Prussian philosopher, government func-tionary, diplomat, and founder of the Humboldt University of Berlin, which was named after him in 1949 (and also after his younger brother, Alexander von Humboldt, a naturalist). $\mathrm{He}$ is especially remembered as a linguist who made important contributions to the philosophy of language and to the theory and practice of education. In particular, he is widely recognized as having been the architect of the Humboldtian education ideal, which was used from the beginning in Prussia as a model for its system of education and eventually in countries such as the $\underline{\mathrm{US}}$ and $\underline{\text { Japan}}$. His younger brother, Alexander rasiona-lisme yang menganggap bahwa bahasa adalah bagian yang tidak dapat dipotong-potong atau diklasifi-kasikan seperti pada pendapat aliran empirisme.

\section{SIMPULAN DAN SARAN}

Bahasa Arab dan psikoli-nguistik, kedua memiliki relevansi yang harmonis, dimana bahasa Arab merupakan induk dari seluruh ca-bang disiplin ilmu bahasa Arab, yang terdiri dari komponen dan kete-rampilan berbahasa. Pertama, meliputi ashwat (fonologi); mufradat (vocabularies); dan qawa'id (grama-tika). Sementara kedua, mencakup maharat alIstima' (listening skill); maharat alKalam (speaking skill); maharat alQira'ah (reading skill); dan maharat alKitabah (writing skill). Adapun psikolinguistik adalah salah satu bagian dari cabang ilmu bahasa, sehingga ia merupakan da-lam kategori komponen bahasa. Selanjutnya, bahasa Arab dan psiko-linguistik niscaya dikaji secara konseptual dan historis, karena kedua disiplin ilmu dimaksud masing-masing memiliki konsepsi dan his-toris. Bahasa Arab secara konseptual dan historis dijadikan sebagai bahasa fital dalam ibadah shalat oleh umat Islam seluruh dunia, sedangkan psi-kolinguistik secara konseptual dan historis merupakan gabungan dua disiplin ilmu baru, yaitu ilmu psi-kologi dan ilmu linguistik. Dan disiplin ilmu ini muncul permulaan abad ke-20 atau tahun 1954, sementara di Indonesia disiplin ilmu ini diterapkan pertama kali di Uni-versitas Atma Jaya Jakarta tahun 1998 pada Strata Satu (S-1) Jurusan Bahasa. Sedangkan, aktualisasi de-sain psikolinguistik dalam pembe-lajaran bahasa Arab di era globalisasi saat ini adalah merupakan aktualisasi empat komponen kandungan

von Humboldt, was famous as a geographer, naturalist, and ex-plorer. (Wikipedia.org). 
kuriku-lum terdiri dari desain tujuan pembelajarannya; desain konten pembelajarannya; desian pendekatan, stra-tegi, metode dan teknik pembela-jarannya; serta desain evaluasi pem-belajaran yang digunakan dan di-aplikasikan oleh dosen pada suatu institusi tertentu. Selanjutnya, bagi peneliti yang memang menjadi fokus kajiannya, untuk mencermati lebih jauh tentang Bahasa Arab dan Psikolinguistik se-cara konseptual terkait dengan relevansinya dalam pembelajaran bahasa Arab. Hal ini dapat dilakukan melalui proses eksplorasi dan tela'ah kritis terhadap konsep dan teori yang dimunculkan oleh para pakar profe-sional dalam disiplin ilmu Bahasa Arab dan Psikolinguistik yang notabene fokus dalam konteks tersebut.

\section{DAFTAR PUSTAKA}

Abu Shalih, Badruddin, (Tanpa Tahun), al-Madkhal ila al-Lughah alArabiyyah, Beirut: Dar al-Syarq alArabi, Cet. Ke-2

Al-Khuli, Ali, Muhammad, (1986), Asalib Tadris al-Lughah al-Arabiyah, Riyadh: al-Mamlakah al-Arabiyah al-Syu'udiyah, Cet. Ke-2

Abdu al-Muhsin, Yusri, (Tanpa Tahun), al-Murahiqat Wa al-Thib al-Nafsi, al-Qahirah: Dar al-Huriyyah.

Abbas, Faishal (1990), Asalib Dirasah alSyakhshiyyah: al-Taknikatu alIsqathiyyah, Beirut: Dar al-Fikr alLubnani, Cet.Ke-1

Asrori, Imam (2004), Sintaksis Bahasa Arab Frasa-Klausa-Kalimat, Malang: Misykat, Cet. Ke-1

Al-Khathib, Halaa (2007), Ta'allam Kaifa Tuwazin Hayatak: Sit Quwa Tu'idu Ilaika Thaqatuka Wa 'Azimatuka,
al-Riyad: al-Mamlakah al-Arabiyah al-Su'udiyah, Cet.Ke-1

Chaer, Abdul (2003), Psikolinguistik: Kajian Teoretik, Jakarta: PT Rineka Cipta, Cet.Ke-1

Chomsky, Noam (1977), Language and Mind, New York: Harcourt Broce Jovanovich, Inc.

Dardjowidjojo, Soenjono (2003), Psikolinguistik Pengantar Pemahaman Bahasa Manusia, Jakarta: Yayasan Obor Indonesia, Cet.ke-1

Ibn Ibrahim, Nashir (Tanpa Tahun), Tarikh Ilm al-Lughah al-Nafsi $\mathrm{Wa}$ Ahdafuhu, al-Madinah alMunawwarah: al-Mamlakah alArabiyah al-Su'udiyah.

Ibrahim Abdu al-Karim, Muhammad (2007), Lughah al-Jasad alNafsiyah, Dimasyqo: Dar 'Ala' alDin, Cet.Ke-1

Ilyan, Mahmud, Fuad, Ahmad (1992), alMaharat al-Lughawiyah; Mahiyatuha wa Taraiq Tadrisiha, Riyad: Dar al-Muslim, Cet. Ke-1

Kamal, Deeb, Abu (1971), Al-Jurjani's Theory of Poetic Imagery and its Background, Ph.D, Thesis, Oxford University, England, Fi Majallah al-Jami'ah al-Islamiyah, al-'Adad 154.

Ka'wash, Aziz (2010), Ilm al-Lughah alNafsi: Baina al-Adabiyah alLisaniyah Wa al-Dirasat alNafsiyah, Baskarah: Majallah Kulliyat al-Adab Wa al-Ulum alInsaniyah Wa al-Ijtima'iyah, al'Adad al-Sabi'. 
Khawis, Mu'in (2003), Fan al-'Ilaj alNafsi, Dimasyqo: Dar 'Ala' al-Din, Cet.Ke-2

Mahjub, Fatimah, (Tanpa Tahun), Dirasat Fi Ilm al-Lughah, al-Qahirah: Dar al-Nahdhah al-Arabiyah.

Qasis, Umar (2014), Iktisyaf Thabai'i alNas Wa Thuruq al-Ta'amul Ma'ahum: Tathbiq Ilm al-Nafs $\mathrm{Fi}$ Makan al-'Amal Wa Fi al-Usrah, Dimasyqo: Wizarah al-Tsaqafah, Cet.Ke-1.

Simanjuntak, Magantar (1990), Pengantar Psikolinguistik Modern, Kualalumpur: Dewan Bahasa dan Pustaka.

Syamsuddin, Jalal (Tanpa Tahun), Ilm alLughah al-Nafsi: Manahijuhu Wa Nadzariyatuhu Wa Qadhayahu, alIskandariyah: Mu'assasah alTsaqafah al-Jami'iyah, Jilid-1.

------ (Tanpa Tahun), Ilm alLughah al-Nafsi: Manahijuhu Wa Nadzariyatuhu Wa Qadhayahu, alIskandariyah: Mu'assasah alTsaqafah al-Jami'iyah, Jilid-2. 